\title{
Optimizing Islamic Education Towards the Golden Era of Indonesia
}

\author{
Received: 03-11-2021 \\ Revised: 07-01-2022 \\ Accepted: 17-01-2022
}

Muhammad Annas Budiarto', Unik hanifah salsabila ${ }^{2}$

Faculty of Islamic Religion, Ahmad Dahlan University, Indonesia ${ }^{1,2}$

muhammad1900031300@webmail.uad.ac.id, unik.salsabila@pai.uad.ac.id

\begin{tabular}{|c|c|}
\hline & Abstract \\
\hline Keywords: & \multirow{12}{*}{$\begin{array}{l}\text { Optimizing Islamic education plays an important role in preparing } \\
\text { Indonesian citizens to excel in quality in terms of education in } \\
\text { welcoming Indonesia's golden era. Optimizing education leads to } \\
\text { maximizing human resources, especially for school students. They are } \\
\text { the main encouragement during the golden era because they are } \\
\text { entering a productive period. This article aims to provide an } \\
\text { understanding of how important educational factors are in preparing } \\
\text { for the golden age of Indonesia by analyzing the urgency and } \\
\text { designing the steps to be used. This study uses the library research } \\
\text { method, using pragmatic content analysis, thematic content analysis, } \\
\text { analysis of sign means, continued by processing it into new data where } \\
\text { the results of this study are the exposure of optimizing education to } \\
\text { reach the golden era of Indonesia from reviewing and analyzing and } \\
\text { integrating various related reference sources. }\end{array}$} \\
\hline & \\
\hline $\begin{array}{l}\text { Islamic Education, } \\
\text { Golden Era, }\end{array}$ & \\
\hline Indonesia & \\
\hline & \\
\hline & \\
\hline & \\
\hline & \\
\hline & \\
\hline & \\
\hline & \\
\hline & \\
\hline
\end{tabular}

\section{Kata Kunci:}

Optimalisasi,

Pendidikan

Islam, Generasi

Emas. Indonesia

\begin{abstract}
Abstrak
Optimalisasi pendidikan Islam berperan penting dalam mempersiapakan warga negara Indonesia unggul secara kualitas dari segi pendidikan dalam menyambut masa keemasan Indonesia (golden era). Dalam proses pengoptimalisaian pendidikan mengarah memaksimalkan sumber daya manusia khusunya bagi siswa sekolah karena mereka dorongan utama saat golden era karena memasuki masa produktif. Artikel ini bertujuan untuk memberikan pemahaman sebarapa penting faktor pendidikan mempersiapkan masa keemasan Indonesia dengan menganalisis urgensi dan merancangan langkah langkah yang di gunakan. Artikel ini mengunakan metode library research, menggunakan analisis isi pragmatic. analisis isi tematik, dan analisis sarana tanda. Kemudian dilanjutkan dengan mengolahnya menjadi data baru yang di mana hasil penelitian ini adalah pemaparan optimalisasi pendidikan untuk menuju golden era Indonesia dari menelaah dan menganalisis serta menyatukan berbagai sumber referensi terkait.
\end{abstract}

http://pasca.jurnalikhac.ac.id/index.php/tijie/index 


\section{INTRODUCTION}

The very goal that will be achieved will not be separated from the basic development, one of which is in terms of education. There won't be a success that can be achieved without knowledge and brain content that is not qualified. Education is a very important thing for the Indonesian state and not maybe a non-priority, because in the state constitution, namely the 1945 Constitution in the opening mentions "educating the nation's life" so that education is the main goal, no Indonesian citizen should not get freedom in education, because basic education is a human right of every citizen so that every human being on earth Indonesia has the right to get quality and high-quality education of course following the interests and talents of each individual regardless of everything egocentric issues such as ethnicity, ethnicity, gender, religion, social status, and status economy. ${ }^{1}$ Then in the 1945 Constitution Chapter of education Article 31 explained that before continuing education in tune with talent interest, every citizen is required to attend basic education, and the government is obliged to finance these activities.

The golden era of Indonesia is the golden age of Indonesia, where that era was characterized by the predominant productive age ( $<40$ years) and high quality. because at that age humans tend to be more serious at work and do something. From the explanation above, there is the word quality or quality which means quality means to have something more than other individuals. ${ }^{2}$ Very important that we should take that era seriously. Therefore start from as early as possible every citizen has a high awareness. On this concept of consciousness, Antonio Gramsci in the book State and Hegemony explains that awareness is a condition in which every individual is can understand situatithe on and condition of the character of the community where you live (observe), then narrows that the individual is an intellectual (a person who uses the ability to move forward. ${ }^{3}$

The explanation above and related to the words of Prof. Rein indicates that education is the most important impetus in preparing for the golden age of Indonesia, signaling that the government should be more observant and comprehensive in making 13.

\footnotetext{
${ }^{1}$ Aminuddin Bakry, "Kebijakan pendidikan sebagai kebijakan publik," Jurnal Medtek 2, no. 1 (2010): 12 Mujamil Qomar, Dimensi manajemen pendidikan Islam (Emir, 2013).

${ }^{3}$ Nezar Patria, Antonio Gramsci: Negara dan Hegemoni (Pustaka Pelajar, 1999).
} 
policies related to, ${ }^{4}$ there should be no gap that makes education cannot be felt by every citizen, facilitate access to education both in terms of facilities and administration, there should be no ambiguity in making policies such as the curriculum education, educational exams. from the most basic level (SD) to college height 5 .

The most urgent affirmation in running to build a good education quality and relevance is to analyze all policies. ${ }^{6}$ For avoiding ambiguous policies is not enough to be literate to issues that yes, read more books, pay attention to the constitution but also be able to analyze which policies can be applied carefully considering Indonesian culture to realize human resources that are qualified to support the beauty of the country. ${ }^{7}$ The discussion of the golden era is not a new problem but already existed when the country became independent, brought Indonesia from developing countries to become developed countries, more sovereign, just, and prosperous as ideals of the country written on Pancasila. ${ }^{8}$

\section{RESEARCH METHODS}

In this study, the author uses the library research method, namely the which collects library data and then compiles it into one part. The reason researchers use this method is that that ten read about focthe uson education and development of the country both in terms of history and analysis of the coun in the future, making it easier to search for data and find research results.

The steps in this research are reading the data source (reference understanding and examining the object being read after that write concise but weighty. Sources used in this study used a variety of literary sources such as magazines, articles, journals, books, and other references that contain concrete data in the discussion?.

\footnotetext{
4 Damsar, Pengantar Sosiologi Pendidikan (Kencana, 2011).

${ }^{5}$ Afifuddin Harisah, Filsafat Pendidikan Islam Prinsip dan Dasar Pengembangan (Deepublish, 2018).

${ }^{6}$ Kay Colthorpe dkk., "Drivers for authenticity: student approaches and responses to an authentic assessment task," Assessment \& Evaluation in Higher Education 46, no. 7 (3 Oktober 2021): 995-1007, https://doi.org/10.1080/02602938.2020.1845298.

7 Tracey Yani Harjatanaya dan Chang-Yau Hoon, "Politics of multicultural education in post-Suharto Indonesia: a study of the Chinese minority," Compare: A Journal of Comparative and International Education 50, no. 1 (2 Januari 2020): 18-35, https://doi.org/10.1080/03057925.2018.1493573; Dyah Putri Fadillah dan Istikomah Istikomah, "The Strategy Of School Literacy Culture In Elementary School," Nazhruna: Jurnal Pendidikan Islam 4, no. 3 (19 Oktober 2021): 503-17, https://doi.org/10.31538/nzh.v4i3.1614.

8 Binti Maunah, "Stratifikasi Sosial Dan Perjuangan Kelas Dalam Perspektif Sosiologi Pendidikan," Ta'allum: Jurnal Pendidikan Islam 3, no. 1 (1 Juni 2015): 19-38, https://doi.org/10.21274/taalum.2015.3.1.1938.

9 Imam Gunawan, “Metode penelitian kualitatif," Jakarta: Bumi Aksara 143 (2013).
} 
The data taken in this study were sourced from literacy, both from journals and magazines books, in digital or manual forms that focus on optimization education and the golden era of Indonesia. Data analysis was carried out using the method content (Content Analysis) starting from the pragmatic content analysis, continued with Content Analysis thematically divided into three categories, namely analysis of appointment, characterization and the third statement and analysis is the Analysis of Signs, and the process is carried out sorting, comparing, combining and selecting various actual meanings and relevant.

\section{RESULT AND DISSCUSION}

\section{Understanding Optimizing Education for the Golden Era}

Optimizing education towards the golden era are steps, how is education a major factor in supporting the quality of resources? human resources to prepare superior humans in the golden age of the country Indonesia. By collecting data or literature from all problems in the education sector, then analyze the extent to which education policy formed by the government can accommodate the problem or not, and that will produce a form of criticism and suggestions to realize a better education as good as. ${ }^{10} \mathrm{UU}$ no. 39 of 1999, article 22 paragraph 3 explains human rights Humans guarantee that citizens have, issue, and distribute opinion according to what he feels both in writing and verbally and in guaranteeing their freedom. Therefore we as citizens of a developed country must have critical reasoning to be able to analyze all forms of unrest, then able to make suggestions in dealing with all problems ${ }^{11}$

Before moving towards optimizing the education sector, most importantly Paulo explained that there is three-level of human consciousness, namely magical consciousness, naive consciousness, and consciousness critical12, in magical awareness explains humans feel helpless and all have been arranged by God, then naive consciousness means that humans are aware of oppression but chooses to be indifferent and indifferent, while critical awareness Humans are aware that they are oppressed and

10 Syarifah Ismail, “Tinjauan Filosofis Pengembangan Fitrah Manusia dalam Pendidikan Islam,” AtTa'dib 8, no. 2 (14 Desember 2013), https:// doi.org/10.21111/at-tadib.v8i2.510.

11 Ahmad Taufiq, "Pengembangan Kesadaran Kritis di Pesantren dalam Menghadapi Tantangan Revolusi Industri 4.0," Prosiding Nasional 2 (2019): 75-100.

12 Paulo Freire, Pendidikan kaum tertindas (LP3ES, 2000). 
want to fight to get rights. ${ }^{13}$ So, if you want to build comprehensive reasoning, every individual must have critical awareness in dealing with forms of inequality, ambiguity, and inequality in the state.

Optimization comes from the word optimal which means the best, the highest, profitable, to be the highest. So, the meaning of optimization is a process, action, or methodology to make something more effective, perfect, and functional. Therefore, showing the notion of optimizing education is actions or processes that make the field of education more broadly ${ }^{14}$.

In the explanation of Bung Karno's Trisakti book towards the golden era of Indonesia, The golden era of Indonesia is the golden age of Indonesia which is marked by age productive to be the most quantity and have high quality. It is estimated that fall in 2025-2035, but in 2020 to 2021 the world will not accept that Indonesia is experiencing a difficult period, namely the COVID-19 pandemic, so that all sectors from health, economy to education experience setbacks or critical times so that there will be setbacks time in reaching the golden age of the country. ${ }^{15}$

But don't be pessimistic. Due to the pandemic problem, Indonesia is a rich country and financial management remains based on the 1945 Constitution as a constitution and Pancasila as the basis for the concept of a state. In article 33 of the 1945 Constitution explain as it should in the management of the national economy, namely the economy is structured as a joint effort based on the principle of kinship. That matter be proof that the economic system developed is not based on competition and not a very individualistic principle, therefore the government must be able to control the economy into deep it in line with common interests. ${ }^{16}$

From the explanation above, it can be concluded that optimization education to get to the golden era of Indonesia is a process of making education becomes more effective and functional in building and supporting individual critical reasoning to

13 Zarkasyi Zarkasyi, Asnil Aidah Ritonga, dan Wahyudin Nur Nasution, “Internalization of Islamic Religious Education Values in Scouting Extracurricular Activities in Forming Student Character in Public Middle School 2 Peunaron East Aceh," Budapest International Research and Critics Institute (BIRCI-Journal): Humanities and Social Sciences 3, no. 2 (8 Mei 2020): 838-48, https://doi.org/10.33258/birci.v3i2.911.

14 Elly Manizar, “Optimalisasi Pendidikan Agama Islam Di Sekolah,” Tadrib: Jurnal Pendidikan Agama Islam 3, no. 2 (2018): 251, https://doi.org/10.19109/tadrib.v3i2.1796.

15 Paharizal, Trisakti Bung Karno untuk golden era Indonesia, cetakan pe (Yogyakarta: media pressindo, 2014).

16 Ade Wahidin, "Filosofi Manusia Sebagai Pendidik," Edukasi Islami: Jurnal Pendidikan Islam 4, no. 07 (25 Oktober 2017): 197, https://doi.org/10.30868/ei.v4i07.70. 
realize the golden age of Indonesia. ${ }^{17}$ In explanation, the golden era focuses more on industrial and consumptive problems in society, however, in creating a progressive society, progress is also needed, because it makes education as a basic point towards the golden era is very appropriate.

\section{The Urgency of Optimizing Education Towards the Golden Era}

With a short description in his understanding, sparking about why should there be optimization in the field of education. In the history of education, Indonesia has 10 The curriculum has changed several times, starting from 1947 which is called the Learning Plan 1947 but can only be applied in 1950 until the latest Curriculum 2013 or $\mathrm{K}-13^{18}$, which continues today. The curriculum is fundamental and is pursuing the educational goals that are designed. However, Curriculum changes are never separated from the existing polemics. ${ }^{19}$ As well as $\mathrm{K}-13$, which is currently being used, there are not a few noisy problems with its presence the new curriculum, starting from the unpreparedness of the educators when presenting the material, regional disparities with one another, even economic problems related to books must be updated with a very large number. So that means must there is an objective reading of the situation accompanied by a mature readiness to create or design a curriculum. ${ }^{20}$

Talking about the curriculum cannot be separated from existing education policies, a policy that is implemented will have an impact prolonged, such as how the character of students who want to be built, what knowledge is prioritized, what learning concepts are applied.21 Therefore policies must be systematic and objective, not forgetting to also obsobserve field situation to collect what kind of educational data wanted $\mathrm{d}$ by the Indonesian people but still the basic guidelines that have been set.

17 Endang Syarif Nurulloh, “Pendidikan Islam dan Pengembangan Kesadaran Lingkungan,” Jurnal Penelitian Pendidikan Islam 7, no. 2 (3 November 2019): 237, https://doi.org/10.36667/jppi.v7i2.366.

18 R Ibrahim, “Kurikulum dan pembelajaran," Jakarta: Rajagrafindo Persada, 2012.

19 Nur Ahid dan Nur Chamid, "Implementation of Indonesian National Qualification Framework Based Curriculum in Higher Islamic Education," Jurnal Pendidikan Islam 7, no. 1 (30 Juni 2021): 109-22, https://doi.org/10.15575/jpi.v7i1.12425.

20 Poetri Leharia Pakpahan dan Umi Habibah, “Manajemen Program Pengembangan Kurikulum PAI Dan Budi Pekerti Dalam Pembentukan Karakter Religius Siswa: Management of IRE Curriculum Development Program and Character in Forming Student's Religious Character," Tafkir: Interdisciplinary Journal of Islamic Education 2, no. 1 (10 Januari 2021): 1-20, https://doi.org/10.31538/tijie.v2i1.19.

${ }^{21}$ Naïma Lafrarchi, “Assessing Islamic Religious Education Curriculum in Flemish Public Secondary Schools," Religions 11, no. 3 (Maret 2020): 110, https:/ / doi.org/10.3390/rel11030110. 
Policy analysis is needed to evaluate the approach objective and accurate scientific analysis, if the results of the policy analysis are not quite accurate to the target, then becomes a consequence for reviewing education policy..$^{22}$

Then reviewed in terms of payment. Financial problems sometimes happen sensitive matters in the conversation, every educational institution has no one with the same financing, some are very expensive, quite expensive, cheap, and free so that the means that can also be different. The book of educational politics explains the problems that arise due to gaps in business education payments ${ }^{23}$. Apart from each institution which differs in payment, should also be homework for the government so that it can manage finance well. Looking back at the 1945 Constitution Article 31 paragraph 4 explains that "At least $20 \%$ of state revenue funds are allocated to the education" concrete that the State must be objective in the use of funds income to be able to start the distribution of both curriculum, policies and educational facilities issue.

Apart from the education sector, the Golden era is more focused on the education industrial field. In the initial explanation, the golden era highlighted the problems of the community consumptive Indonesia, dependence and independence in the field of industrial. In the book future, shock ${ }^{24}$ explained that the consumptive society is people who always change goods, even though the goods used are still good and fit for use (Turow society) and can only be used without being able to create, then the meaning of dependence and independence is people who are too dependent on imported goods. Indeed, Indonesia is capable of exports, but most of the exports are natural products that are still raw, not yea $t$ form of creativity. Paharizal mentions the dominant factor that causes Indonesian society to be not independent and dependence cannot be separated from the effects Existing capitalism includes: 1) Trapped Consumptive culture a. Always update brand new, b. easily bored with old stuff, c. Shopaholic. 2) Not independent in managing natural resources a. Always import without thinking to create a self, $b$. choose to work abroad (TKI) c. Export vendor of raw goods 3) Foreign domination of the economy a. Massive foreign investment $b$. foreigners mastering natural resources, $c$. Its

22 Amirul Mukminïn dkk., "Bilingual Education Policy and Indonesian Students' Learning Strategies," İlköğretim Online 17, no. 3 (31 Juli 2019): 0-0, https:/ / doi.org/10.17051/ilkonline.2018.466330.

${ }_{23}$ Paulo Freire Paulo Freire, "Politik Pendidikan: Kebudayaan, Kekuasaan dan Pembebasan" (Pustaka Pelajar, 2007).

${ }^{24}$ Alvin Toffler, Future shock (Bantam, 1970). 
privacy from BUM. Seeing such a critical reality, then really need evaluation in the realm of socialization and understanding to the community Indonesia from an early age How to Be Critical and Creative ${ }^{25}$.

Examining some of the problems above creates a domino effect on the results obtained, the administrative problems of each educational institution will certainly affect, ranging from learning methods to infrastructure. Cannot be denied the gap above will affect the facilities in each instant, see remote areas for access to go to school locations sometimes it is already difficult, let alone accessing infrastructure such as metropolitan cities. and means will affect the process of learning development, not to mention this era of all focus on technology and industry.

It can be concluded that the elaboration of the urgency of optimizing education to achieve Indonesia's golden era is (1) Planning, Change and Improvement of Curriculum have a long reading (2) Analysis of educational policies that must be appropriate with the needs and character of the Indonesian people (3) Administrative issues without there is inequality (4) Equitable distribution of educational facilities and infrastructure (5) Directing Indonesian people become critical and creative individuals. ${ }^{26}$

\section{The Goal of Optimizing Education Towards the Golden Era}

A psychology figure, namely prof. kohnstam explains there are stages of human develutionopment related to the way of thinking or acting, he divides it into several developments ranging from; vital period (0.0 -2.0 years) i.e early life, the aesthetic period (2.0-7.0 years), namely the development of the five senses, the period of intellectual property (7.0-13 years) which is a mature period for a child to enter formal education (SD), the social/ adolescent period (13/14.0-20/21.0 years) which is the period of seeking fake guidelines or identity as well as selection and assessment. ${ }^{27}$

With the understanding and urgency in optimizing education to support Indonesia to reach its golden age, of course, there is a goal concrete to be achieved, to make a gradual effect on the continuity of rotation direction of motion continues, Some objectives are described as follows;

25 Paharizal, Trisakti Bung Karno untuk golden era Indonesia.

26 Samsul Hadi, Dedek Andrian, dan Badrun Kartowagiran, “Evaluation Model for Evaluating Vocational Skills Programs on Local Content Curriculum in Indonesia: Impact of Educational System in Indonesia," Eurasian Journal of Educational Research 19, no. 82 (31 Juli 2019): 45-62.

27 Winardi A Gerungan, "Psikologi sosial," 1988. 
The first is to grow and develop a paradigm critical thinking of students, by applying the educational curriculum according to the time so that by building critical reasoning the students can become citizens who develop quality in keeping with the times $^{28}$, does not stop at being critical in addressing the problem, but also giving a solution a constructive solution.

The second is creating quality human resources. Look, Indonesia is one of the countries with the largest population, so it must also excel in quality besides being superior in quality. With the existence of government policies that favor the common interest, the government must coordinate how the development of basic training from all sectors to equip each citizen. Not only training but also in education, there must be an increase in the quality of learning, which can make everyone think ahead. ${ }^{29}$

Third, realizing local products to be classy. Many products are good local, but the majority of people still choose imported products because the price is more affordable and people think imported goods are more durable old ${ }^{30}$. People are less able to see what local products are superior due to lack of marketing and lack of socialization of local government in raising small industries, it is necessary to have an umbrella that can accommodate the local industries are then socialized to the wider community. ${ }^{31}$

Fourth is to make Indonesia a prosperous country, fair and prosperous. With an increase in HR that is built from as early as possible, then developed massively and optimally in education to create quality citizens, so they can be creative and innovative take advantage of abundant natural resources, and build a development economy together.

\section{Stages of Optimizing Education Towards the Golden Era}

In the Law on Education, Number 20 of 2003 Article 1 explains about conscious and planned efforts in creating a learning atmosphere and process learning activities of students actively upgrade their potential it has. Then linked to Law No. 39 of 1999 on

\footnotetext{
${ }^{28}$ Ridwan Abdullah Sani, "Pembelajaran saintifik untuk implementasi kurikulum 2013” (Bumi Aksara, 2014).

${ }^{29}$ Sedya Santosa dan Aulia Diana Devi, “The Problematics Online Lectures on Human Resource Management Courses (HRM) at The Islamic College Level," Nazhruna: Jurnal Pendidikan Islam 4, no. 2 (20 Juni 2021): 261-71, https:// doi.org/10.31538/nzh.v4i2.1452.

30 Bayu Dwi Anggono dan Emanuel Raja Damaitu, "Penguatan Nilai-Nilai Pancasila Dalam Pembangunan Nasional Menuju Indonesia Emas," Pancasila: Jurnal Keindonesiaan, 2021, 34-44.

31 Janice A. Dole dan Gale M. Sinatra, "Social Psychology Research on Beliefs and Attitudes: Implications for Research on Learning From Text," dalam Beliefs About Text and Instruction with Text (Routledge, 1995).
} 
Human Rights, chapter 12 mentions several points where one of them is everyone has the right to receive protection and obtain a quality education. Furthermore, it is associated with Law number 24 of 2019 concerning the creative economy which has the core of the creative economy as the embodiment of added value from the wealth sourced from human creativity based on cultural heritage, technology, and science education. This can be a judicial basis plus urgency now is the time to make efforts to realize optimization education to realize Indonesia's golden age, with the following steps: following.

The first is improving the quality of education. Quality improvement is directed as the basis for the next steps, starting from improving the quality of incoming and outgoing graduates up to administrative management. ${ }^{32}$ The main factor in the influence of quality education lies in the learning process because quality education lies in the process of learning activities. ${ }^{33}$ Many things can be done to improve the quality of education in Indonesia, one of which is to increase literacy or reading books. Don't let the process be just a pseudonym, but rather the objective of the process, so that the better the learning process, the better the quality of education. ${ }^{34}$

Education here is still general, not limited to formal education but also with non formal and informal education. Because in the process it can't be perfect if it's done in a school environment but also outside of school, such as informal education carried out in the community family. In informal education, parents have a very important role vital in nurturing their children, especially in the field of spirituality. ${ }^{35}$

Continuing the stage of Peer Equality at the school, then start focusing on the school environment, each teacher essentially assumes the mandate and heavy responsibility to fight for the goals of national education, as the spearhead in educating citizens and manifestations continuity of state life. Therefore, agility is needed, sincerity, skill, and appearance that attracts colleagues to be easier to carry out all program activities with

32 M. Rafiquddin Nasution, Mesiono Mesiono, dan Yusuf Hadijaya, “Management of The Academic Potential of Students During The Covid-19 Pandemic," Nidhomul Haq : Jurnal Manajemen Pendidikan Islam 6, no. 2 (14 September 2021): 470-82, https:// doi.org/10.31538/ndh.v6i2.1658.

33 Shing-lung Chen dan Yeu-Ting Liu, "Learning by designing or learning by playing? A comparative study of the effects of game-based learning on learning motivation and on short-term and long-term conversational gains," Interactive Learning Environments 0, no. 0 (6 Agustus 2021): 1-15, https://doi.org/10.1080/10494820.2021.1961159.

34 Muhammad Fadhli, “Manajemen Peningkatan Mutu Pendidikan," Tadbir: Jurnal Studi Manajemen Pendidikan 1, no. 2 (18 Desember 2017): 215-40, https:/ / doi.org/10.29240/jsmp.v1i2.295.

35 Rahmat Rifai Lubis, “Optimalisasi Kecerdasan Spiritual Anak,” Jurnal Al-Fatih 1, no. 1 (2018): 1-18. 
peer support. Need in also mention the function of the principal, with the authority and authority it should be able to lead and guide teachers and provide uniform direction awareness of the meaning of the teacher's duties and responsibilities in supporting the goals of education as well as the equality of teachers ${ }^{36}$, do not forget to regulate communication traffic between school residents, especially educators so that they do not miscommunication occurs.

Then optimizing the means of supporting activities. To support everything for activities carried out in the school environment, pre -facilities are needed which allows the activities to be carried out. The facilities here are not only books adequate, but such as classrooms, laboratories, IT equipment (science) technology) as well as all the tools used to support all learning activities which is not small in number. With the progress of the times like the industrial revolution 4.0 tools such as computers and ICT learning must be considered, don't let students are not able to join hands with the demands of the world because of inadequate school facilities ${ }^{37}$. Then renovations and repairs must also be massive is done so that students feel comfortable when learning, not worrying about being damaged when used which is of course according to the procedure. Such as chairs, tables, blackboards, and the building must be able to be used in all conditions without hindering the concentration of learning learners.

Furthermore, related party support. Existing ideas don't appear that way without any external factors, in this case, the government, especially the government that overshadows and cultivates education and society. Can't be for teachers to decide policies without involving the government, everything that is implemented must be by the law, existing curriculum policies, this relationship is analogous to executive activities that are under legislative supervision. The supervisory role from above is easier to direct because it is in the top-down form which means that it has a basis and a little more coercive power so that it can be carried out simultaneously and together. Likewise, the surrounding community must be get involved even though its nature is less able to have a terrible impact because of its nature bottom-up or difficult to raise because there is no

36 Yeni Wulandari dan Muhammad Kristiawan, "Strategi sekolah dalam penguatan pendidikan karakter bagi siswa dengan memaksimalkan peran orang tua," JMKSP (Jurnal Manajemen, Kepemimpinan, dan Supervisi Pendidikan) 2, no. 2 (2017): 290-302.

37 Wina Dwi Puspitasari, “Pengaruh Sarana Belajar Terhadap Prestasi Belajar Ilmu Pengetahuan Sosial Di Sekolah Dasar," Jurnal Cakrawala Pendas 2, no. 2 (2016). 
$\operatorname{legitimacy} .^{38}$

But regardless of who is more involved, it must be known together that All of the above elements cannot be separated. Whatever the strategic choice, we still have to be oriented to the intellectual literacy of the abngasa, so that whatever pattern you choose, use regardless of the axis. All educational programs and actions are part of the great struggle to create a better future so that it can reach the golden age of the country.

Then improving the quality of educators. With all the upgrades that need to be in do, then next discuss how to improve the quality of energy educators. It has been explained that the teacher is the spearhead in world education, therefore it needs to be sharpened as sharply as possible to create teacher quality. There are several examples of improvement, ranging from teacher certification (providing educator certificates to teachers, provided that they meet the standard professional teachers), then teacherprinting institutions must be more selective in particular colleges, increasing competence with a lot of training, workshops and seminar. Blueprints or designs of prospective teachers and other things that relate to the improvement and repair of 39

Continued by Providing Extracurricular to improve non-academic abilities. Extracurricular is supporting activity or additions that are carried out outside of learning hours or school hours, which have many benefits, one of which is as a means to develop potential outside of academics as well as insightful knowledge in helping to shape students according to the interests of each individual. ${ }^{40}$ There are even compulsory extracurriculars that exist and are followed by all students, explained in Law number 12 of 2010 concerning the scouting movement, scouting is set to be a mandatory extracurricular activity in primary education and secondary education. ${ }^{41}$

There is also carrying out training related to the world of work. This is especially in upper secondary education (high school or equivalent) because basically after graduating from high school they enter the adult phase so they rarely jump into the world of work. SMK (Vocational High School) has the concept of practical and

38 Ikramullah Ikramullah dan Akhmad Sirojuddin, “Optimalisasi Manajemen Sekolah Dalam Menerapkan Pendidikan Inklusi Di Sekolah Dasar," Munaddhomah: Jurnal Manajemen Pendidikan Islam 1, no. 2 (25 April 2020): 131-39, https://doi.org/10.31538/munaddhomah.v1i2.36.

39 Dwi Esti Andriani, “Mutu Guru Dan Implikasinyaterhadap Mutu Pendidikan," Jurnal Manajemen Pendidikan UNY, 2009, 112615.

40 Ria Yuni Lestari, “Peran Kegiatan Ekstrakurikuler Dalam Mengembangkan Watak Kewarganegaraan Peserta Didik," Untirta Civic Education Journal 1, no. 2 (28 Desember 2016), https://doi.org/10.30870/ucej.v1i2.1887.

${ }^{41}$ Haidar Putra Daulay, Pendidikan Islam dalam Perspektif Filsafat (Kencana, 2014). 
theoretical education, while in MA (Madrasah Aliyah) and SMA (High School) is very little that teaches about work practices and so on, so it is necessary to hold long and have a follow-up in developing basic skills in the world of work when they will pass choose not to continue to college or education thereafter, students have at least a basic working knowledge. ${ }^{42}$

The last stage is conducting an evaluation. Broadly speaking, evaluation has the meaning of the process of measuring, correcting, assessing, and improving a program or activities carried out by comparing the planning process with the results achieved, in this contest, of course, in the education sector. ${ }^{43}$ There are a lot of functions namely selective function, diagnostic function, fungus placement, and measurement success. So, it is concrete that this educational evaluation needs to be done schedule and be carried out gradually and continuously.

\section{The Importance of Islamic Education for Optimizing Future Education}

Next, we review the point of view of optimizing education for students to support the golden era of Indonesia from the perspective of Islamic education. Islamic education has 3 domains, namely At Tarbiyah which has the meaning of the transfer process knowledge from an educator to students with the aim of form piety, character, and good personality, $A l \mathrm{Ta} \mathrm{a}^{\prime} \mathrm{lim}$ means the process of teaching and $A l \mathrm{Ta}$ ' dib has a pivotal point in civilization and culture.44 So, the definition of Islamic education can be interpreted as a system that allows individuals (students) to direct their lives according to their Islamic religious ideology, of course, with the basis of the Qur'an and Sunnah, as well as directions Islamic education is more aimed at the nature of God (Tawhid) which realizing individuals have good deeds for themselves and personally universal. ${ }^{45}$

\footnotetext{
${ }^{42}$ Christy Prisilia Lumintang, “Lingkungan Kerja, Pelatihan, Dan Gaya Kepemimpinan Kepala Sekolah Dan Pengaruhnya Terhadap Prestasi Kerja Guru-Guru Smk Negeri 1 Manado," Jurnal Berkala Ilmiah Efisiensi 16, no. 1 (29 April 2016), https:/ / ejournal.unsrat.ac.id/index.php/jbie/article/view/12053.

${ }^{43}$ Munaya Ulil Ilmi dkk., "The Basic Concepts of Evaluation and Its Implementation in IRE Lessons in The Pandemic Era," Tafkir: Interdisciplinary Journal of Islamic Education 2, no. 2 (30 Juli 2021): 175-90, https://doi.org/10.31538/tijie.v2i2.50; Rola Ajjawi dkk., "Aligning assessment with the needs of workintegrated learning: the challenges of authentic assessment in a complex context," Assessment E Evaluation in Higher Education 45, no. 2 (17 Februari 2020): 304-16, https:/ / doi.org/10.1080/02602938.2019.1639613.

${ }_{44}$ Muhammad Ridwan, “Konsep Tarbiyah, Ta'lim Dan Ta'dib Dalam Al-Qur'an,” Nazhruna: Jurnal Pendidikan Islam 1, no. 1 (16 Agustus 2018): 37-60, https:/ / doi.org/10.31538/nzh.v1i1.41.

${ }^{45}$ Haidir Haidir, Muhammad Arizki, dan Miftah Fariz, "An Innovation of Islamic Religious Education in The Era of The Industrial Revolution 4.0 in Elementary School," Nazhruna: Jurnal Pendidikan Islam 4, no. 3 (9 November 2021): 720-34, https://doi.org/10.31538/nzh.v4i3.1688.
} 
Seeing that Islamic education focuses on education morals and character, this is considered very important in supporting optimization education to support the golden era of Indonesia. According to the point of view, the psychology of adolescence or commonly called the period of fake guidance and social mass mark with curiosity and tries new things that he wants to know. Rachman said that today's teenagers have a tendency, 46 then it should be considered seriously, adolescence is marked with curiosity and try new things that he wants to know. Rachman said that today's teenagers have a tendency persuasive against sex outside of marriage, plus according to BNN data that today's teenagers are not a few who are caught in drug cases. ${ }^{47}$

Therefore, Islam is a great wall that prevents things from happening Munkar, must be able to enter the soul of today's youth with education. ${ }^{48}$ It doesn't have to be applied to Islam only, but also with non-Muslim students, because basically, Islamic education has a universally applicable purpose or spirit of provetik. ${ }^{49}$

\section{CONCLUSION}

Optimalisasi Optimizing education towards the golden era of Indonesia is everything in the form of the process of making education better to support and prepare every citizen towards the golden age of Indonesia. Optimization of this education is important because it serves as the basis for the formation of character and way of thinking of each individual. Indonesia's golden period was marked by the dominant productive age total population of citizens. The purpose of this optimization is 1) Growing paradigm critical thinking 2) Education as a quality human resource printer 3) creating creative, innovative, and superior local products 4) realizing a fair Indonesia, prosperous and prosperous. In optimizing education towards the golden era Indonesia requires objective and concrete stages and does not create gaps, the steps are 1) Quality improvement education, 2) Peer equality in schools, 3) Optimization of supporting facilities activities, 4) Support from related parties, 5) Improving the quality of educators, 6) Providing Extracurricular to improve non-academic abilities 7), Implement training

\footnotetext{
46 Indriani Pratami, "Pemikiran Transformatif Politik Islam Kuntowijoyo Ditinjau Dari Perspektif Filsafat Politik" (Yogyakarta, Universitas Gadjah Mada, 2019), http:/ / etd.repository.ugm.ac.id/penelitian/detail/170836.

47 Diah Ningrum, “Kemerosotan moral di kalangan remaja: Sebuah penelitian mengenai parenting styles dan pengajaran adab," Unisia 37, no. 82 (2018): 18-30.

48 Qosim Nursheha Dzulhadi, "Islam sebagai Agama dan Peradaban," TSAQAFAH 11, no. 1 (30 November 2015): 151-68, https://doi.org/10.21111/tsaqafah.v11i1.258.

${ }^{4}$ Heddy Shri Ahimsa-Putra, Paradigma Profetik Islam: Epistemologi Etos Dan Model (Yogyakarta: UGM PRESS, 2019).
} 
related to the world of work, 8) Carrying out evaluations. How Islamic education can realize expectations of the improvement of morality that we are facing now, starting from small things such as etiquette to the problem of adolescent and social acquaintance at this time. And it is also hoped that Islam as the religion of the majority of Indonesia can have character respect each other so that it is not only optimal in life education but also in everyday life.

\section{REFERENCES}

Ahid, Nur, dan Nur Chamid. "Implementation of Indonesian National Qualification Framework Based Curriculum in Higher Islamic Education." Jurnal Pendidikan Islam 7, no. 1 (30 Juni 2021): 109-22. https:// doi.org/10.15575/jpi.v7i1.12425.

Ahimsa-Putra, Heddy Shri. Paradigma Profetik Islam: Epistemologi Etos dan Model. UGM PRESS, 2019.

- - - . Paradigma Profetik Islam: Epistemologi Etos Dan Model. Yogyakarta: UGM PRESS, 2019.

Ajjawi, Rola, Joanna Tai, Tran Le Huu Nghia, David Boud, Liz Johnson, dan Carol-Joy Patrick. "Aligning assessment with the needs of work-integrated learning: the challenges of authentic assessment in a complex context." Assessment $\mathcal{E}$ Evaluation in Higher Education 45, no. 2 (17 Februari 2020): 304-16. https://doi.org/10.1080/02602938.2019.1639613.

Andriani, Dwi Esti. “Mutu Guru Dan Implikasinyaterhadap Mutu Pendidikan.” Jurnal Manajemen Pendidikan UNY, 2009, 112615.

Anggono, Bayu Dwi, dan Emanuel Raja Damaitu. “Penguatan Nilai-Nilai Pancasila Dalam Pembangunan Nasional Menuju Indonesia Emas." Pancasila: Jurnal Keindonesiaan, 2021, 34-44.

Bakry, Aminuddin. "Kebijakan pendidikan sebagai kebijakan publik." Jurnal Medtek 2, no. 1 (2010): 1-13.

Chen, Shing-lung, dan Yeu-Ting Liu. "Learning by designing or learning by playing? A comparative study of the effects of game-based learning on learning motivation and on short-term and long-term conversational gains." Interactive Learning Environments 0, no. 0 (6 Agustus 2021): 1-15. https://doi.org/10.1080/10494820.2021.1961159. 
Colthorpe, Kay, Harrison Gray, Louise Ainscough, dan Hardy Ernst. “Drivers for authenticity: student approaches and responses to an authentic assessment task." Assessment \& Evaluation in Higher Education 46, no. 7 (3 Oktober 2021): 995-1007. https://doi.org/10.1080/02602938.2020.1845298.

Damsar. Pengantar Sosiologi Pendidikan. Kencana, 2011.

Daulay, Haidar Putra. Pendidikan Islam dalam Perspektif Filsafat. Kencana, 2014.

Dole, Janice A., dan Gale M. Sinatra. "Social Psychology Research on Beliefs and Attitudes: Implications for Research on Learning From Text." Dalam Beliefs About Text and Instruction with Text. Routledge, 1995.

Dzulhadi, Qosim Nursheha. "Islam sebagai Agama dan Peradaban.” TSAQAFAH 11, no. 1 (30 November 2015): 151-68. https:// doi.org/10.21111/tsaqafah.v11i1.258.

Fadhli, Muhammad. “Manajemen Peningkatan Mutu Pendidikan.” Tadbir : Jurnal Studi Manajemen Pendidikan 1, no. 2 (18 Desember 2017): 215-40. https://doi.org/10.29240/jsmp.v1i2.295.

Fadillah, Dyah Putri, dan Istikomah Istikomah. “The Strategy Of School Literacy Culture In Elementary School." Nazhruna: Jurnal Pendidikan Islam 4, no. 3 (19 Oktober 2021): 503-17. https://doi.org/10.31538/nzh.v4i3.1614.

Freire, Paulo. Pendidikan kaum tertindas. LP3ES, 2000.

Gerungan, Winardi A. “Psikologi sosial,” 1988.

Gunawan, Imam. “Metode penelitian kualitatif." Jakarta: Bumi Aksara 143 (2013).

Hadi, Samsul, Dedek Andrian, dan Badrun Kartowagiran. "Evaluation Model for Evaluating Vocational Skills Programs on Local Content Curriculum in Indonesia: Impact of Educational System in Indonesia." Eurasian Journal of Educational Research 19, no. 82 (31 Juli 2019): 45-62.

Haidir, Haidir, Muhammad Arizki, dan Miftah Fariz. “An Innovation of Islamic Religious Education in The Era of The Industrial Revolution 4.0 in Elementary School." Nazhruna: Jurnal Pendidikan Islam 4, no. 3 (9 November 2021): 720-34. https://doi.org/10.31538/nzh.v4i3.1688.

Harisah, Afifuddin. Filsafat Pendidikan Islam Prinsip dan Dasar Pengembangan. Deepublish, 2018.

Harjatanaya, Tracey Yani, dan Chang-Yau Hoon. "Politics of multicultural education in post-Suharto Indonesia: a study of the Chinese minority." Compare: A Journal of 
Comparative and International Education 50, no. 1 (2 Januari 2020): 18-35. https:/ / doi.org/10.1080/03057925.2018.1493573.

Ibrahim, R. “Kurikulum dan pembelajaran.” Jakarta: Rajagrafindo Persada, 2012.

Ikramullah, Ikramullah, dan Akhmad Sirojuddin. “Optimalisasi Manajemen Sekolah Dalam Menerapkan Pendidikan Inklusi Di Sekolah Dasar." Munaddhomah: Jurnal Manajemen Pendidikan Islam 1, no. 2 (25 April 2020): 131-39. https://doi.org/10.31538/munaddhomah.v1i2.36.

Ilmi, Munaya Ulil, Farid Setiawan, Maulida Nurul Hikmah, Arrum Kharisma, Dimas Feryawan, dan Aiman Affan Hanafie. “The Basic Concepts of Evaluation and Its Implementation in IRE Lessons in The Pandemic Era." Tafkir: Interdisciplinary Journal of Islamic Education 2, no. 2 (30 Juli 2021): 175-90. https://doi.org/10.31538/tijie.v2i2.50.

Ismail, Syarifah. “Tinjauan Filosofis Pengembangan Fitrah Manusia dalam Pendidikan Islam." At-Ta'dib 8, no. 2 (14 Desember 2013). https://doi.org/10.21111/attadib.v8i2.510.

Lafrarchi, Naïma. "Assessing Islamic Religious Education Curriculum in Flemish Public Secondary Schools." Religions 11, no. 3 (Maret 2020): 110. https://doi.org/10.3390/rel11030110.

Lestari, Ria Yuni. “Peran Kegiatan Ekstrakurikuler Dalam Mengembangkan Watak Kewarganegaraan Peserta Didik." Untirta Civic Education Journal 1, no. 2 (28 Desember 2016). https:// doi.org/10.30870/ucej.v1i2.1887.

Lubis, Rahmat Rifai. “Optimalisasi Kecerdasan Spiritual Anak.” Jurnal Al-Fatih 1, no. 1 (2018): 1-18.

Lumintang, Christy Prisilia. “Lingkungan Kerja, Pelatihan, Dan Gaya Kepemimpinan Kepala Sekolah Dan Pengaruhnya Terhadap Prestasi Kerja Guru-Guru Smk Negeri 1 Manado." Jurnal Berkala Ilmiah Efisiensi 16, no. 1 (29 April 2016). https://ejournal.unsrat.ac.id/index.php/jbie/article/view/12053.

Manizar, Elly. “Optimalisasi Pendidikan Agama Islam Di Sekolah." Tadrib: Jurnal Pendidikan Agama Islam 3, no. 2 (2018): 251. https:// doi.org/10.19109/tadrib.v3i2.1796.

Maunah, Binti. “Stratifikasi Sosial Dan Perjuangan Kelas Dalam Perspektif Sosiologi Pendidikan." Ta'allum: Jurnal Pendidikan Islam 3, no. 1 (1 Juni 2015): 19-38. https://doi.org/10.21274/taalum.2015.3.1.19-38. 
Mukminin, Amirul, Eddy Haryanto, Sutarno Sutarno, Siti RAHMA Sari, Lenny Marzulïna, Hadiyanto Hadiyanto, dan Akhmad Habibi. "Bilingual Education Policy and Indonesian Students' Learning Strategies." Illköğretim Online 17, no. 3 (31 Juli 2019): 0-0. https:/ / doi.org/10.17051/ilkonline.2018.466330.

Nasution, M. Rafiquddin, Mesiono Mesiono, dan Yusuf Hadijaya. “Management of The Academic Potential of Students During The Covid-19 Pandemic." Nidhomul Haq : Jurnal Manajemen Pendidikan Islam 6, no. 2 (14 September 2021): 470-82. https://doi.org/10.31538/ndh.v6i2.1658.

Ningrum, Diah. “Kemerosotan moral di kalangan remaja: Sebuah penelitian mengenai parenting styles dan pengajaran adab." Unisia 37, no. 82 (2018): 18-30.

Nurulloh, Endang Syarif. "Pendidikan Islam dan Pengembangan Kesadaran Lingkungan." Jurnal Penelitian Pendidikan Islam 7, no. 2 (3 November 2019): 237. https://doi.org/10.36667/jppi.v7i2.366.

Paharizal. Trisakti Bung Karno untuk golden era Indonesia. Cetakan pe. Yogyakarta: media pressindo, 2014.

Pakpahan, Poetri Leharia, dan Umi Habibah. "Manajemen Program Pengembangan Kurikulum PAI Dan Budi Pekerti Dalam Pembentukan Karakter Religius Siswa: Management of IRE Curriculum Development Program and Character in Forming Student's Religious Character." Tafkir: Interdisciplinary Journal of Islamic Education 2, no. 1 (10 Januari 2021): 1-20. https:/ / doi.org/10.31538/ tijie.v2i1.19.

Patria, Nezar. Antonio Gramsci: Negara dan Hegemoni. Pustaka Pelajar, 1999.

Paulo Freire, Paulo Freire. "Politik Pendidikan: Kebudayaan, Kekuasaan dan Pembebasan." Pustaka Pelajar, 2007.

Pratami, Indriani. "Pemikiran Transformatif Politik Islam Kuntowijoyo Ditinjau Dari Perspektif Filsafat Politik." Universitas Gadjah Mada, 2019. http://etd.repository.ugm.ac.id/penelitian/detail/170836.

Puspitasari, Wina Dwi. "Pengaruh Sarana Belajar Terhadap Prestasi Belajar Ilmu Pengetahuan Sosial Di Sekolah Dasar." Jurnal Cakrawala Pendas 2, no. 2 (2016).

Qomar, Mujamil. Dimensi manajemen pendidikan Islam. Emir, 2013.

Ridwan, Muhammad. "Konsep Tarbiyah, Ta'lim Dan Ta'dib Dalam Al-Qur'an." Nazhruna: Jurnal Pendidikan Islam 1, no. 1 (16 Agustus 2018): 37-60. https://doi.org/10.31538/nzh.v1i1.41. 
Tafkir: Interdisciplinary Journal of Islamic Education

Sani, Ridwan Abdullah. "Pembelajaran saintifik untuk implementasi kurikulum 2013." Bumi Aksara, 2014.

Santosa, Sedya, dan Aulia Diana Devi. “The Problematics Online Lectures on Human Resource Management Courses (HRM) at The Islamic College Level." Nazhruna: Jurnal Pendidikan Islam 4, no. 2 (20 Juni 2021): 261-71. https://doi.org/10.31538/nzh.v4i2.1452.

Taufiq, Ahmad. "Pengembangan Kesadaran Kritis di Pesantren dalam Menghadapi Tantangan Revolusi Industri 4.0." Prosiding Nasional 2 (2019): 75-100.

Toffler, Alvin. Future shock. Bantam, 1970.

Wahidin, Ade. "Filosofi Manusia Sebagai Pendidik." Edukasi Islami: Jurnal Pendidikan Islam 4, no. 07 (25 Oktober 2017): 197. https:// doi.org/10.30868/ei.v4i07.70.

Wulandari, Yeni, dan Muhammad Kristiawan. "Strategi sekolah dalam penguatan pendidikan karakter bagi siswa dengan memaksimalkan peran orang tua." JMKSP (Jurnal Manajemen, Kepemimpinan, dan Supervisi Pendidikan) 2, no. 2 (2017): 290-302.

Zarkasyi, Zarkasyi, Asnil Aidah Ritonga, dan Wahyudin Nur Nasution. “Internalization of Islamic Religious Education Values in Scouting Extracurricular Activities in Forming Student Character in Public Middle School 2 Peunaron East Aceh." Budapest International Research and Critics Institute (BIRCI-Journal): Humanities and Social Sciences 3, no. 2 (8 Mei 2020): 838-48. https://doi.org/10.33258/birci.v3i2.911. 